\title{
Chromosomal aberrations in infective hepatitis
}

\author{
N. MATSANIOTIS, K. KIOSSOGLOU, F. MAOUNIS, AND \\ D. ANAGNOSTAKIS \\ From the Choremis Research Laboratory, Department of Paediatrics, University of Athens, \\ St Sophie's Children's Hospital, Goudi, Athens, Greece
}

SYNOPSIS Structural chromosomal aberrations, in the form of breaks, were found in a significantly higher proportion of bone marrow cells in patients with infective hepatitis than in controls. These anomalies were observed during the first and third weeks after the onset of jaundice but had subsided by the sixth week.

Chromosomal aberrations did not appear to be related to the severity of infective hepatitis or to the sex or age of the patients.

The distribution of chromosomal abnormalities did not appear to be random; they were observed predominantly in the $A_{2}$ and $B_{4-5}$ series. Since no abnormalities were detected in the G-group chromosomes, no evidence in support of a relationship between infective hepatitis and Down's syndrome was obtained.

Numerical chromosomal aberrations were not observed, nor was any evidence obtained that mitotic activity of bone marrow cells is suppressed in patients with infective hepatitis.

Structural chromosomal aberrations have been described in patients with various viral diseases, such as measles (Aula, 1965; Nichols, Levan, Hall, and Östergren, 1962; Nichols and Levan, 1965), chickenpox (Aula, 1963, 1965; Massimo, Vianello, Dagna-Bricarelli, and Tortorolo, 1965), and mumps (Aula, 1965), as well as in subjects vaccinated against yellow fever (Harnden, 1964) or measles (Nichols, 1963).

Similar chromosomal changes have been shown to occur in tissue cultures infected by herpes simplex virus (Hampar and Ellison, 1961), simian virus 40 (Koprowski, Ponten, Jensen, Ravdin, Moorhead, and Saksela, 1962; Moorhead and Saksela, 1963), or oncogenic viruses (Shein and Enders, 1962).

It, therefore, appeared interesting to investigate whether chromosomal aberrations may be caused by infective hepatitis, especially in view of its probable epidemiological association with Down's syndrome (Stoller and Collmann, 1966).

Preliminary results from a small number of Received for publication 6 March 1970. children studied between the first and the 18th days after the onset of jaundice have already been reported (Matsaniotis, Kiossoglou, Maounis, and Anagnostakis, 1966).

Chromosomal findings in the bone-marrow cells of 27 children in the active phase of infective hepatitis and during remission are described.

\section{Material and Methods}

Twenty-seven children admitted to the Paediatric Clinic of Athens University from March to December 1966, in whom the diagnosis of infective hepatitis was well documented on both clinical and laboratory grounds, were included in the study.

Eleven patients were males and 16 females. Their ages ranged from 2 to 14 years. Their mental and sexual development was normal. None had been previously exposed to any form of $x$-ray radiation or drug therapy. 
Chromosomal studies in direct bone-marrow preparations were performed during the icteric phase, one to six days following the onset of jaundice; during the phase of obvious clinical improvement, 15 to 20 days after the onset of jaundice, and during remission when the serum levels of bilirubin, and glutamic-oxaloacetic and glutamic-pyruvic transaminases approached normal limits.

Forty-four bone-marrow preparations were obtained, 21 during the first week, 16 during the third, and seven during the sixth week following the onset of jaundice.

The bone marrow was examined once in 15 patients, twice in seven, and three times in the remaining five patients.

Twenty-one patients with no viral disease, or haematological or neoplastic disorder, matched for age and sex, served as controls.

Chromosomal studies were carried out according to the method previously described (Kiossoglou, Mitus, and Dameshek, 1964). The combined Denver (1960) and Patau (1961) systems of nomenclature were used.

Coded material was used when reading patient and control slides.

\section{Results}

The number of patients examined, the time of examination, and the incidence of normal and abnormal findings are illustrated in detail in Table I.

\begin{tabular}{|c|c|c|c|c|c|c|c|c|}
\hline & $\begin{array}{l}\text { No. of } \\
\text { Patients }\end{array}$ & $\begin{array}{l}\text { No. of Bone- } \\
\text { marrow Pre- } \\
\text { parations }\end{array}$ & \multicolumn{2}{|c|}{$\begin{array}{l}\text { First } \\
\text { Week }\end{array}$} & \multicolumn{2}{|c|}{$\begin{array}{l}\text { Third } \\
\text { Week }\end{array}$} & \multicolumn{2}{|c|}{$\begin{array}{l}\text { Sixth } \\
\text { Week }\end{array}$} \\
\hline Once & 15 & 15 & \multicolumn{2}{|l|}{11} & \multicolumn{2}{|l|}{4} & \multicolumn{2}{|c|}{ - } \\
\hline Twice & 5 & 10 & \multicolumn{2}{|l|}{5} & \multicolumn{2}{|l|}{5} & \multicolumn{2}{|c|}{ - } \\
\hline Twice & 2 & 4 & \multicolumn{2}{|l|}{-} & \multicolumn{2}{|l|}{2} & \multicolumn{2}{|c|}{2} \\
\hline Thrice & 5 & 15 & \multicolumn{2}{|l|}{5} & \multicolumn{2}{|l|}{5} & \multicolumn{2}{|c|}{5} \\
\hline Total & 27 & 44 & \multicolumn{2}{|l|}{21} & \multicolumn{2}{|l|}{16} & \multicolumn{2}{|c|}{7} \\
\hline \multirow{2}{*}{\multicolumn{3}{|c|}{$\begin{array}{l}\text { Chromosomal findings } \\
\text { No. of bone-marrow prepara- } \\
\text { tions }\end{array}$}} & $\mathbf{A}$ & $\mathbf{N}$ & $\mathbf{A}$ & $N$ & $\mathbf{A}$ & $\mathbf{N}$ \\
\hline & & & 12 & 9 & 12 & 4 & 1 & 6 \\
\hline
\end{tabular}

Table I Findings in current series

A $=$ abnormal, $\mathbf{N}=$ normal

The number of mitotic figures encountered in each preparation was about 20 in both patients and controls.

\begin{tabular}{|c|c|c|c|c|c|c|c|}
\hline \multirow{2}{*}{$\begin{array}{l}\text { No. of } \\
\text { Children }\end{array}$} & \multirow{2}{*}{$\begin{array}{l}\text { No. of } \\
\text { Cells } \\
\text { Examined }\end{array}$} & \multicolumn{4}{|c|}{ Number of Chromosomes } & \multirow{2}{*}{$\begin{array}{l}\text { No. of } \\
\text { Aneuploid } \\
\text { Cells }\end{array}$} & \multirow{2}{*}{$\begin{array}{l}\text { No. of } \\
\text { Cells with } \\
\text { Structural } \\
\text { Aberrations }\end{array}$} \\
\hline & & $<46$ & 46 & $>46$ & Polyploid & & \\
\hline $\begin{array}{l}21 \\
\text { Percentage }\end{array}$ & 430 & $\begin{array}{l}26 \\
6 \cdot 0\end{array}$ & $\begin{array}{l}387 \\
90 \cdot 0\end{array}$ & $\begin{array}{l}2 \\
0 \cdot 5\end{array}$ & $\begin{array}{l}15 \\
3 \cdot 5\end{array}$ & $\begin{array}{l}28 \\
6 \cdot 5\end{array}$ & $\begin{array}{c}5 \\
1 \cdot 2\end{array}$ \\
\hline
\end{tabular}

Table II Numerical and structural chromosomal aberrations in the control group

\begin{tabular}{|c|c|c|c|c|c|c|}
\hline \multirow{2}{*}{$\begin{array}{l}\text { No. of } \\
\text { Patients }\end{array}$} & \multirow{2}{*}{$\begin{array}{l}\text { No. of } \\
\text { Cells } \\
\text { Examined }\end{array}$} & \multicolumn{4}{|c|}{ Number of Chromosomes } & \multirow{2}{*}{$\begin{array}{l}\text { No. of } \\
\text { Aneuploid } \\
\text { Cells }\end{array}$} \\
\hline & & $<46$ & 46 & $>46$ & Polyploid & \\
\hline $\begin{array}{l}27 \\
\text { Percentage }\end{array}$ & 780 & $\begin{array}{l}63 \\
8 \cdot 0\end{array}$ & $\begin{array}{l}690 \\
88 \cdot 5\end{array}$ & $\begin{array}{c}3 \\
0 \cdot 4\end{array}$ & $\begin{array}{l}24 \\
3 \cdot 1\end{array}$ & $\begin{array}{l}66 \\
8 \cdot 4\end{array}$ \\
\hline
\end{tabular}

Table III Numerical chromosomal aberrations 27 patients

NUMERICAL CHROMOSOMAL ABERRATIONS A total of 780 and 430 metaphase plates derived respectively, from 27 patients and 21 controlsowere counted and analysed on photomicro? graphs. The number of chromosomes ranged fromo 40 to 60 in both groups. The incidence of aneuploid cells was $8.4 \%$ in the patients and $6.5 \%$ in the controls. The number of polyploid cell $\delta$ was within the normal range, namely, $3 \cdot 1 \stackrel{0}{0}$ and $3.5 \%$ respectively (Tables II and III). Thy pattern was normal in all cells with 46 chromog somes. In the hypodiploid cells the loss of chro mosomes was random.

STRUCTURAL CHROMOSOMAL

ABERRATIONS

Isolated chromatid and isochromatid break and gaps were found in five out of 21 controls The incidence of chromosomal aberrations was $1 \cdot 2 \%$ (Table II).

Single or multiple chromatid and isochromatiz breaks and gaps, acentric fragments, secondar constrictions, and minute chromosomes were demonstrated in 12 out of 21 patients during the first week, in 12 out of 16 patients during thio third week, and in one out of seven patients. during the sixth week, following the onset \&f jaundice (see Table I and Figures 1-3).

The number of affected cells and the incidenge of aberrations during the first, third, and the sixth weeks following the onset of jaundice shown in Table IV.

The incidence of cells showing structur $\$$ abnormalities was $9.6 \%$ and $11.3 \%$, respectivels during the first and third weeks, and $0.7 \%$ during the sixth week. The difference in the number of cells with structural aberrations between the patients and the controls was statif tically highly significant $(P<0.001)$. Since man of the affected cells showed more than one aberration, in the group of patients the inciden $\overline{\bar{c}}$ of chromosomal abnormalities was $17.3 \%$ ar\& $19.8 \%$ during the first and third weeks, respect ively, ie, higher than that of cells with structure aberrations $(9.6 \%$ and $11.3 \%)$. No structural changes were seen during the sixth week follop ing the onset of jaundice.

In seven patients no chromosomal aberration. were detected (Table IV). 


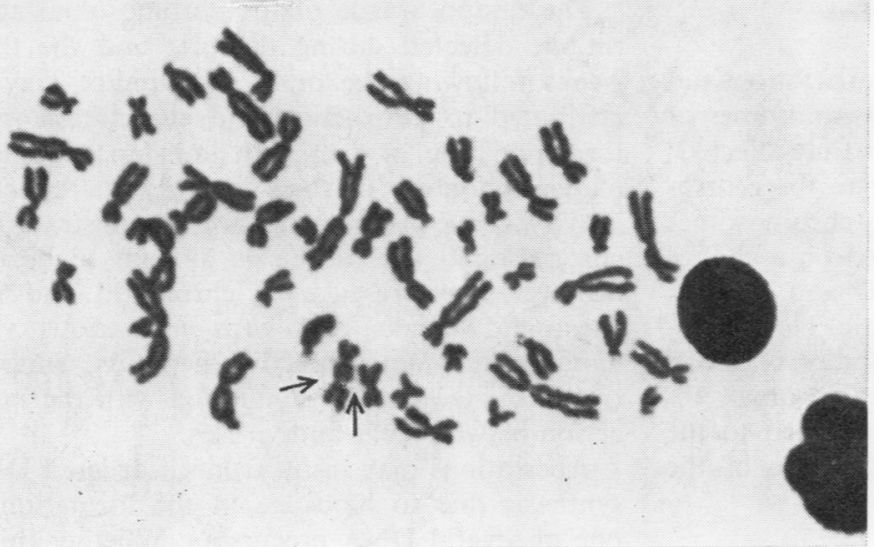

FIG. 1

FIG. 2

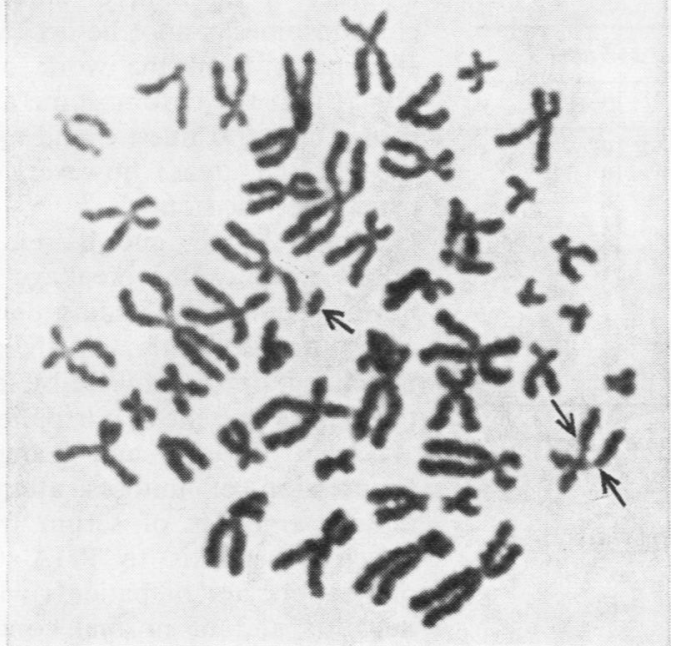

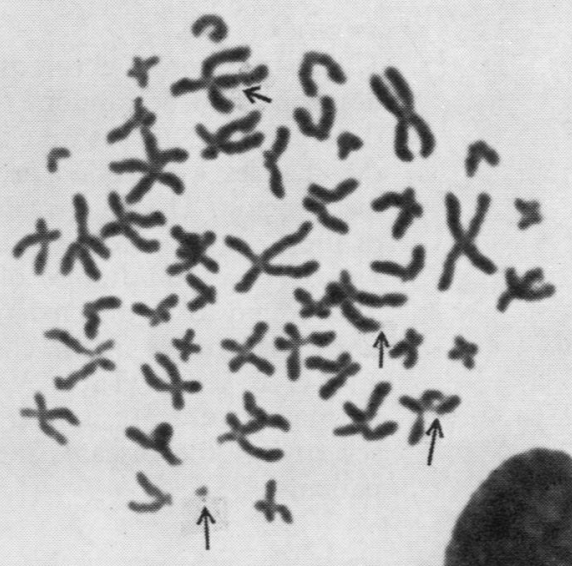

FIG. 3

Fig. 1 Bone-marrow metaphase plate containing 46 chromosomes. The arrows point to isochromatid breaks in a $B_{4-5}$ chromosome $(\times 3,000)$.

Fig. 2 Bone-marrow metaphase plate containing 46 chromosomes. The arrows point to chromatid break and isochromatid gaps in A and C-group chromosomes, respectively $(\times 3,000)$.

Fig. 3 Bone-marrow metaphase plate containing 46 chromosomes plus one fragment. The arrows point to chromatid gaps, deletion, and fragment in $A$, $B$, and C-group chromosomes $(\times 2,500)$.

\begin{tabular}{|c|c|c|c|c|c|c|c|c|c|c|}
\hline \multirow{2}{*}{$\begin{array}{l}\text { Case } \\
\text { No. }\end{array}$} & \multicolumn{3}{|c|}{ First Week } & \multicolumn{3}{|c|}{ Third Week } & \multicolumn{3}{|c|}{ Sixth Week } & 옴 \\
\hline & $\begin{array}{l}\text { No. Cells } \\
\text { Examined }\end{array}$ & $\begin{array}{l}\text { No. Affected } \\
\text { Cells }\end{array}$ & $\begin{array}{l}\text { No. Chromo- } \\
\text { somes } \\
\text { Aberrant }\end{array}$ & $\begin{array}{l}\text { No. Cells } \\
\text { Examined }\end{array}$ & $\begin{array}{l}\text { No. Affected } \\
\text { Cells }\end{array}$ & $\begin{array}{l}\text { No. Chromo- } \\
\text { somes } \\
\text { Aberrant }\end{array}$ & $\begin{array}{l}\text { No. Cells } \\
\text { Examined }\end{array}$ & $\begin{array}{l}\text { No. Affected } \\
\text { Cells }\end{array}$ & $\begin{array}{l}\text { No. Chromo } \\
\text { somes } \\
\text { Aberrant }\end{array}$ & o- \\
\hline 1 & 15 & 6 & 13 & - & - & - & - & - & - & \\
\hline 2 & 13 & 2 & 7 & - & - & - & - & - & - & \\
\hline 3 & 7 & 0 & 0 & - & - & - & - & - & - & 5 \\
\hline 4 & 32 & 1 & 1 & - & - & - & - & - & - & \\
\hline 5 & 27 & 3 & 7 & - & - & - & - & - & - & 5 \\
\hline 6 & 2 & 0 & 0 & - & - & - & - & - & - & \\
\hline 7 & 10 & 0 & 0 & - & - & - & - & - & - & \\
\hline 8 & - & - & - & 25 & 1 & 1 & - & - & - & \\
\hline 9 & 8 & 4 & 7 & - & - & - & - & - & - & \\
\hline 10 & - & - & - & 15 & 2 & 4 & - & - & - & \\
\hline 11 & - & - & - & 18 & 1 & 3 & - & - & - & \\
\hline 12 & 16 & 1 & 1 & - & - & - & - & - & - & \\
\hline 13 & - & - & - & 15 & 3 & 6 & - & - & - & $<$ \\
\hline 14 & 15 & 0 & $\mathbf{0}$ & 3 & 2 & 7 & - & - & - & \\
\hline 15 & 29 & 0 & 0 & 21 & 2 & 4 & - & - & - & \\
\hline 16 & 3 & 2 & 5 & - & - & - & - & - & - & $\mathbb{\infty}$ \\
\hline 17 & 10 & 2 & 3 & 22 & 3 & 6 & 22 & 0 & 0 & \\
\hline 18 & 17 & 2 & 3 & 24 & 3 & 5 & - & - & - & \\
\hline 19 & - & - & - & 14 & 0 & 0 & 23 & 0 & 0 & \\
\hline 20 & - & - & - & 11 & 4 & 5 & 14 & 0 & 0 & \\
\hline 21 & 19 & 0 & 0 & 10 & 0 & 0 & 20 & 0 & 0 & \\
\hline 22 & 21 & 0 & 0 & 20 & 0 & 0 & 26 & 0 & 0 & \\
\hline 23 & 30 & 4 & 5 & 15 & 3 & 4 & 15 & 0 & 0 & \\
\hline 24 & 20 & 4 & 5 & 27 & 5 & 7 & 25 & 1 & 1 & \\
\hline 25 & 20 & 0 & 0 & 17 & 0 & 0 & - & - & - & \\
\hline 26 & 10 & 0 & 0 & 26 & 3 & 4 & - & - & - & \\
\hline 27 & 28 & 3 & 4 & - & - & - & - & - & - & \\
\hline Tota & $\begin{array}{c}352 \\
\text { centage }\end{array}$ & $\begin{array}{r}34 \\
9 \cdot 6\end{array}$ & $\begin{array}{l}61 \\
17 \cdot 3\end{array}$ & 283 & $\begin{array}{l}32 \\
11.3\end{array}$ & $\begin{array}{l}56 \\
19 \cdot 8\end{array}$ & 145 & $\begin{array}{l}1 \\
0.7\end{array}$ & $\begin{array}{c}1 \\
0.7\end{array}$ & $ב$ \\
\hline
\end{tabular}


DISTRIBUTION OF CHROMOSOMAL

ABERRATIONS

The distribution of chromosomal aberrations did not appear to be random. The chromosomes of the $A_{2}$ and $B_{4-5}$ series were those mainly affected; the changes were found proximal to the centromere region. The abnormalities in chromosomes of the $\mathrm{C}$ series were those expected on a chance basis. The chromosomes of the $D$ and $E$ series were found to be affected very little. No aberrations were noted in the chromosomes of the $F$ and G-Y series (Table V). Chromosomal abnormalities did not appear to be related to the severity of the disease, the sex, or age of the patients.

\begin{tabular}{|c|c|c|}
\hline \multirow{2}{*}{$\begin{array}{l}\text { Chromasomal Series } \\
\left(\text { Denver }^{1} \text { and } \text { Patau }^{2}\right)\end{array}$} & \multicolumn{2}{|c|}{ Chromosomal Aberrations } \\
\hline & Found & Expected \\
\hline $\begin{array}{ll}\text { A }\left\{\begin{array}{l}1 \\
2 \\
3\end{array}\right. \\
\text { B } 4-5 \\
\text { C } & 6-X-12 \\
\text { D } & 13-15 \\
\text { E } & 16-18 \\
\text { F } & 19-20 \\
\text { G } & 21-22 \\
\text { Y } & \end{array}$ & $\begin{array}{r}11 \\
25 \\
4 \\
30 \\
35 \\
4 \\
3 \\
0 \\
0 \\
0\end{array}$ & $\begin{array}{r}10 \\
10 \\
8 \\
13 \\
42 \\
11 \\
8 \\
5 \\
4 \\
2\end{array}$ \\
\hline
\end{tabular}

Table V Distribution of chromosomal aberrations on the various series in 27 patients with infective hepatitis

'Lancet, 1, 1063 (1960). I 'Lancet, 1, 933 (1961).

\section{Discussion}

The results of this study showed that chromosomal aberrations can be found in a considerable proportion of patients with infective hepatitis between the first and the third weeks following the onset of jaundice.

Similar chromosomal changes have been reported in neoplastic disorders (Kiossoglou et al, 1965; Sandberg, Ishihara, Kikuchi, and Crosswhite, 1964). The presence of similar chromosomal aberrations in viral diseases and neoplasias raised a growing interest about the role of viruses in the development of carcinogenesis (Nichols, 1963; Porter, 1963); it was postulated that chromosomal breakage might represent the primary gene mutation, presumably leading to the development of neoplasia.

Whether the chromosomal aberrations demonstrated in this study may be associated in some way with the postulated epidemiological relationship between infective hepatitis and Down's syndrome (Stoller and Collmann, 1966) cannot be decided yet. In any event, no numerical or structural aberrations in the $\mathbf{G}_{21-22}$ series which would support such a relationship between infective hepatitis and Down's syndrome were detected in this study.
The disappearance of the chromosomal aber- $\frac{O}{5}$ rations detected during the first and the third 0 weeks following the onset of jaundice may be $\frac{0}{F}$ attributed to destruction and elimination from $\underline{0}$ the circulation of cells with imbalanced genetic $\overrightarrow{\vec{F}}$ material because of their inability to replicate. $\stackrel{\oplus}{?}$

Why some patients did not demonstrate any? chromosomal aberrations is difficult to decide; $\frac{\bar{\sigma}}{\bar{N}}$ however, the presence of chromatid and iso- $\frac{\bar{\sigma}}{\overline{0}}$ chromatid breaks and gaps in various viral $\stackrel{\mathbb{}}{\varrho}$ diseases, including infective hepatitis, suggests that breakage may be connected with the inter- $\overrightarrow{0}$ action between cells and viruses.

Aberrations may result from disordered DNA $\vec{\omega}$ synthesis due to blockage in the formation of one of several DNA precursors. Whether this iso a direct or an indirect effect of the virus on N $_{\mathrm{E}}$ chromosomes cannot be decided at the moment. $-v$ It appears from the work of Rapp and $\mathrm{Hsu}_{\mathrm{G}}$ (1965) that the chromosome aberrations are not ${ }^{\omega}$ caused by viral nucleic acid synthesis at or nears the affected areas; however, other viral effects cannot be ruled out.

El-Alf, Smith, and Biesele (1965) have pro-응 duced chromosome breakage in cell cultures of normal persons by adding plasma from patients $\vec{\oplus}$ with viral hepatitis; in their cases, however, 0 the changes induced were by far less pronounced. than those present in our patients.

Recently Mella and Lang (1967) reported suppression of mitoses after the addition of minute amounts of serum from patients witho infective hepatitis to PHA-stimulated cultures $\cong$ of lymphocytes of patients with active infective $\overrightarrow{\vec{B}}$ hepatitis and of normal controls. Serum from 3 convalescing patients did not show this suppressive effect, but it did cause structural chromosomal aberrations, which were attributed to celli injury or interference with cell replication by the virus of hepatitis.

On the other hand, Tobias, Safran, and Schaffner (1967) reported more than $80 \%$ trans $-₹$ formation into large lymphoid cells in PHA-O stimulated cultures of lymphocytes from patients? with various liver diseases, including viral hepa-o titis, indicating that the cells were capable of responding promptly.

In our study suppression of mitotic activity of bone-marrow cells was not observed, sincen mitotic figures in numbers comparable to those $e_{0}^{\omega}$ observed in controls were found at all stages of infective hepatitis.

\section{References}

Aula, P. (1963). Chromosome breaks in leukocytes of chickenpor patients. Preliminary communication, Hereditas, 49, 451 453.

Aula, P. (1965). Virus-associated chromosome breakage. A cytogenetic study of chickenpox, measles and mumps patients and of cell cultures infected with measles virus? Ann. Acad. Sci. fenn., 89, 1-78.

Denver Report (1960). A proposed standard system of nomen clature of human mitotic chromosomes. Lancet, 1, 10658 1065. 
El-Alfi, O. S., Smith, P. M., and Biesele, J. J. (1965). Chromosomal breaks in human leukocyte cultures induced by an agent in the plasma of infectious hepatitis patients. Hereditas, 52, 285-294.

Hampar, B., and Ellison, S. A. (1961). Chromosomal aberrations induced by an animal virus. Nature (Lond.), 192, 145-147.

Harnden, D. G. (1964). Cytogenetic studies on patients with virus infections and subjects vaccinated against yellow fever. Amer. J. hum. Genet., 16, 204-213.

Kiossoglou, K. A., Mitus, W. J., and Dameshek, W. (1964). A direct method for chromosome studies of human bone marrow. Amer. J. clin. Path., 41, 183-187.

Kiossoglou, K. A., Mitus, W. J., and Dameshek, W. (1965). Chromosomal aberrations in acute leukemia. Blood, 26, 610-641.

Koprowski, H., Ponten, J. A., Jensen, F., Ravdin, R. G., Moorhead, P., and Saksela, E. (1962). Transformation of cultures of human tissue infected with Simian virus SV 40. J. cell comp. Physiol., 59, 281-292.

Massimo, L., Vianello, M. G., Dagna-Bricarelli, F., and Tortorolo, G. (1965). Chickenpox and chromosome aberrations. Brit. med. J., 2, 172.

Matsaniotis, N., Kiossoglou, K. A., Maounis, F., and Anagnostakis, D. E. (1966). Chromosomes in infectious hepatitis. Lancet, 2, 1421.

Mella, B., and Lang, D. J. (1967). Leukocyte mitosis: suppression in vitro associated with acute infectious hepatitis. Science, $155,80-81$.

Moorhead, P. S., and Saksela, E. (1963). Non-random chromosomal aberrations in SV 40-transformed human cellso?
J. cell comp. Phyotion, $57-83$.

Nichols, W. W. (1963).' Relationships of viruses, chromosomest and carcinogenesis. Hereditas, 50, 53-80.

Nichols, W. W., Levan, A., Hall, B., and Ostergren, G. (1962) Measles-associated chromosome breakage, Preliminary. communication. Hereditas, 48, 367-370.

Nichols, W. W., and Levan, A. (1965). Measles associated chromosome breakage. (Seminar on the epidemiology and prevention of measles and rubella, Paris, June 1964. Arch. ges. Virus-forsch. 16, 168-174.

Patau, K. (1961). Chromosome identification and the Denve report. Lancet, 1, 933-934.

Porter, G. H. (1963). Viruses and cancer. Arch. intern. Med. 111, 572-591.

Rapp, F., and Hsu, T. C. (1965). Viruses and mammalian chromon somes. IV. Replication of herpes simplex virus in diploid Chinese hamster cells. Virology, 25, 401-411.

Sandberg, A. A., Ishihara, T., Kikuchi, Y., and Crosswhite;L. H. (1964). Chromosomes of lymphosarcoma and cancee cells in bone marrow. Cancer (Philad.), 17, 738-746.

Shein, H. M., and Enders, J. F. (1962). Transformation induce by simian virus $\mathbf{4 0}$ in human renal cell cultures. I. Morpho⿰ logy and growth characteristics. Proc. nat. Acad. Sci., 48 in 1164-1172.

Stoller, A., and Collmann, R. D. (1966). Viral hepatitis and Down's syndrome. Lancet, $2,339$.

Tobias, H., Safran, A. P., and Schaffner, F. (1967). Lymphocyte stimulation and chronic liver disease. Lancet, 1, 193-195 